\title{
MÚSICA E CIVILIZAÇÃO EM ADORNO: A ASSIMETRIA DA MÚSICA E A MORTIFICAÇÃO DA AUDIÇÃO
}

\author{
Harley Juliano Mantovani*
}

\begin{abstract}
RESUMO
Nesse texto abordamos, de modo indireto, a constituição de uma estética musical através dos elementos filosóficos, sociológicos e psicanalíticos que condicionam e fazem parte da compreensão da audição como arte. Para isso, defendemos a existência de uma oposição oculta entre a música e o processo civilizatório, como culto da divindade da imagem, que teve como filha a Indústria Cultural, perseguidora dos novos discípulos de Dionísio-oposto-a-Apolo, Schoenberg, Webern e Berg, presos pela inteligência instrumental do diretor Ulisses, que como um trabalhador ao final do expediente, sempre quer voltar para a falsa familiaridade das instituições prontas para nos matarem, com medo do obscuro, do estranho e do diferente, como Penteu. Enfim, foi nosso objetivo demonstrar a relação causal entre a perda da arte da audição e o fetichismo.
\end{abstract}

Palavras-chave: Adorno. Música. Nietzsche. Filosofia. Arte.

\begin{abstract}
In this text we approach, of indirect way, the constitution of a musical esthetic throughout of philosophical, sociological and psychoanalytical elements which are condition and make part of understanding of hearing as art. For this, we defend an existence of a hide opposition between the music and the civilizing process, as cult of divinity of the image, which had as daughter the Cultural Industry, which persecute the news disciples of Dionysus-opposed-the-Apollo, Schoenberg, Webern, and Berg, prisoners by instrumental intelligence of the director Ulisses, which as a worker at end of expedient, always to want to come back for the false intimacy
\end{abstract}

\footnotetext{
* Mestre em Filosofia pela Universidade Federal de São Carlos. Professor do Curso de Filosofia da Faculdade Católica de Uberlândia. E-mail: harleybrief@yahoo.com.br
} 
of the institutions to await to kill us, whit fear of obscure, of strange, of different, as Penteu. Finally, we had as objective to demonstrate the causal relationship between the loss of art of hearing and the fetishism.

Keywords: Adorno. Music. Nietzsche. Philosophy. Art.

O esforço para manter firme o eu prende-se ao eu em todos os seus estágios e a tentação de perdê-lo sempre veio de par com a cega decisão de conservá-lo. (Adorno e Horkheimer. Dialética do Esclarecimento.)

Não nos propusemos uma análise sistemática e pontualmente comparativa entre Adorno e Nietzsche. Por este motivo nos prescindimos, neste momento, de aprofundarmos essa relação para além da mera enunciação da sua possibilidade, que procuramos demonstrar, apenas como um sugestivo pano de fundo, no presente texto. Aqui, defendemos, antes, um modo de leitura do processo civilizatório - desde sua pretensa gênese e consolidação alcançada - através da audição (música e arte) e da visão (imagem e moral), que elegemos ao status de princípios orientadores. Em ambos os filósofos, encontramos a instauração da civilização a partir e através de um processo de encobrimento da essência - em sua obscuridade abismal de fundo sonoro-audível - pela aparência fenomênica cujo brilho artificial reclama e mantém os olhos sem olhar e que buscam narcisicamente a si mesmos. Dionísio foi silenciado pelo Apolo que, não mais aceitando a oposição do deus noturno ${ }^{1}$, desvirtuou-se na racionalidade cujo desdobramento irá se refletir na ratio comercial cujo manejo industrial da música a galvaniza como algo sacro e inquestionável, conforme Adorno (1989, p. 18), para quem, a indústria cultural educa-nos para lhe sermos vítimas, fazendo com que nos aferremos "com tenacidade ainda maior

\footnotetext{
${ }^{1}$ Só há verdadeira reconciliação sobre a base de uma luta incessante, a arte só se desenvolve se ela está ligada à duplicidade do apolíneo e do dionisíaco que define o trágico que teve nascimento e história no espírito da música. Essa contraposição entre a arte apolínea do figurador plástico (Bildner) e a arte não figurada (unbildlichen) da música fundamenta criações verdadeiramente novas, extraídas da perpetuidade da luta enquanto solo extremamente fértil (NIETZSCHE, 1992, p. 27).
} 
à aparência que apaga a essência" (ADORNO, 1989, p. 18)². Erguendose sobre a repressão do lirismo e a correlata mortificação da audição, a civilização basilarmente se estrutura pela correspondência entre debilitação do instinto estético e a moralização através da plástica e da imagem que se quer um fundamento seguro da moralidade, na medida em que a imagem, individualizando e fixando, estabelece a medida harmônica e visível das identidades cuja beleza amaldiçoa o sofrimento, o horrível, o nada ser de plausivamente aceito, como geralmente é o não-eu excêntrico e ameaçador. Nesse movimento de perda do espírito da música e, portanto, de rejeição e convencional condenação do trágico, e que assim impediu o cultivo emancipador da arte da escuta, então assaz condicionada e deseducada pela falta do canto não linguístico que Nietzsche não teve a imodéstia de proferir em $1871^{3}$, já estava prefigurada a indústria cultural que, enquanto racionalização do entretenimento domesticador com suas promessas de fama, de conforto e de felicidade, já era a grande inimiga de Zaratustra em 1885, responsável pela desafinação dos ouvidos então indisponíveis e incapazes de escutarem o fogo trazido para os últimos homens queimarem todos os ídolos como outrora o fez Zaratustra (NIETZSCHE, 1959, p. 17), cuja trágica solidão de criador também experimentaram Schoenberg, Webern e Berg, almas menádicas e vozes igualmente estranhas que não cantaram para ninguém, tal como Assim falava Zaratustra foi um livrocanto escrito para todos e para ninguém que não quisesse conservar sua

2 Essa continuidade e cumplicidade entre o apolíneo e a administração cultural devemse a uma corrupção do apolíneo "princípio esclarecedor" reduzido a "luzes de néon" e o consequente desvirtuamento do Obscuro, por parte da "todo-poderosa indústria cultural", contra a qual se insurge a arte que lança mão da obscuridade para esclarecer o mundo, "tão luminoso na aparência, de suas próprias trevas". Assim ela sobrevive, porque, conforme Adorno, "somente numa humanidade pacificada e satisfeita a arte deixará de viver" (1989).

3 Em sua Tentativa de autocrítica, acertando as contas consigo mesmo, Nietzsche declara: "Aqui falava, em todo caso - isto se confessava com curiosidade e, não menos, com aversão - uma voz estranha, o discípulo de um 'deus desconhecido' ainda (...), uma espécie de alma mística e quase menádica” (...). Ela devia cantar, essa 'alma nova' - e não falar! É pena que eu não me atrevesse a dizer como poeta aquilo que eu tinha então a dizer: talvez eu pudesse fazê-lo" (1992, p. 16). E isto que faltou foi realizado apenas em 1885 depois do aprendizado restaurador do trágico de Zaratustra, que enfrentou essa perda da arte da audição (MACHADO, 2001, p. 11-34). 
identidade egológica e especular através de uma mimese sadomasoquista que se desdobra e alimenta as ilusões fetichistas dos comportamentos metonímicos sem intimidade. Nesses termos, não tanto a continuidade entre Nietzsche e Adorno, mas, serão as consequências da rejeição e da oposição à escuta-música, através da apresentação do modo como esta foi manipulada e amordaçada, que exporemos e analisaremos em linhas gerais.

A desconsideração e o esquecimento históricos, inerentes ao processo civilizatório, da "lírica originária de um povo" (NIETZSCHE, 2007) como imitação de uma natureza artisticamente anterior às figurações fenomênicas, deixaram-nos sem defesas e minaram as nossas forças de resistência à fetichização da música e à consolidação da indústria cultural com todas as suas nocivas consequências que taparam-nos os ouvidos, assim aniquilando nossa individualidade então perdida nas assimetrias entre a música e ela mesma. Sendo a cera em nossos ouvidos, a indústria cultural já se encontrava anunciada na tripulação de Ulisses diante do temor do canto das sereias, então recusado e excluído do trabalho que ora nos ocupa, nós que ainda somos aqueles tripulantes. $\mathrm{O}$ nosso texto tematiza e denuncia os resultados danosos desta despreocupação histórica e sociológica acerca de uma criteriosa investigação sobre a origem da música aquém dos símbolos, da palavra, dos sentimentos e do próprio indivíduo. Nesses termos, apenas para dimensionarmos sua importância, inclusive para o sentido futuro do nosso trabalho, faremos inicialmente uma exposição breve, mas preparatória, sobre essa investigação genética das raízes sonoras pré-simbólicas da palavra ou da sonoridade (Ton) em si.

A lírica original contém em si todos os graus de prazer e desprazer ou sofrimento provenientes de um fundamento originário invisível para nós, e se ele é visualmente não-fenomênico, este fundamento é essencialmente audível. Irrepresentável para todos os homens, ele é um subsolo sonoro (Tonuntergrund), universal e compreensível como uma melodia originária da linguagem pré-linguística e pré-verbal do prazer e desprazer (NIETZSCHE, 2007, p. 172). Há um subsolo não-figurativo que é sonoro ou auditivo. Com isto, a musicalidade é anterior e mais fundamental do que a palavra enunciativa, assim como a audibilidade é em relação às formas visíveis. O que respalda a seguinte afirmação de Nietzsche: "A partir de si mesma, a música pode gerar figuras que, então, serão sempre apenas 
esquemas, como que exemplos de seu conteúdo próprio universal. Como deveria, porém, a figura, a representação, poder, a partir de si mesma, produzir música!" (2007, p. 173). É a própria fetichização industrial da música e a consequente mortificação da audição em prol do olhar que são combatidos e recusados através da descoberta da anterioridade prélinguística e pré-verbal do lírico em relação à imagem historicamente cultuada pela civilização. Com efeito, perplexos nos perguntamos "como o mundo apolíneo do olho, inteiramente imerso no contemplar, deveria poder, a partir de si, produzir o som", a não aparência, "que decerto simboliza uma esfera que está excluída e superada justamente porque o apolíneo está imerso na aparência?" (NIETZSCHE, 2007, p. 174). Em outros termos, como defende Nietzsche, "o prazer na aparência não pode, a partir de si, excitar o prazer na não aparência: o deleite do contemplar só é deleite porque nada nos recorda de uma esfera em que a individualização foi despedaçada e suprimida" (2007, p. 174). Eis como o processo civilizatório da aparência promove e transforma o prazer em conservação da individualidade, quando, na verdade, o prazer tem por fonte o subsolo sonoramente não visível, diante do qual não é mais si mesmo aquele que ouve. Se a visão nos conserva idênticos e se por ela nos repetimos, na audição perdemos nossa identidade, ela é a modificação parturiente do estranho vivencial em nós, na medida em que, no interior da linguagem - o universo infinito da origem sagrada da música - experenciamos o não mais linguístico, o subterrâneo Ton como manifestação do deus supremo em relação ao qual os símbolos não têm mais nenhum significado.

Como conclui Nietzsche, "a origem da música jaz além de toda individuação" (2007, p. 176, grifo do autor), o que demanda uma verdadeira arte não estética da audição cujas condições precisam ser pensadas e definidas. $\mathrm{O}$ que fizemos aqui de forma negativa ao apresentarmos e analisarmos o que não constitui uma arte da audição. Nesses termos, diante da sua urgência com a qual hoje nos deparamos, como deixamos de compreender a audição como uma verdadeira arte?

Antes de tudo, é preciso considerarmos as causas e as consequências do processo histórico da "decadência do gosto musical" que se relaciona, segundo Adorno, a uma ambiguidade inerente a experiência da música, qual seja, "a música constitui, ao mesmo tempo, a manifestação imediata 
do instinto humano e a instância própria para o seu apaziguamento" (ADORNO, 1999, p. 65), isto é, a música tem uma realidade empírica, física e sensória, pela qual ela incide e enfatiza a corporeidade humana em seus aspectos mais naturais, materiais e primitivos, mas, por outro lado, ela tem uma realidade que transcende qualquer manifestação imediata ou fenomênica. No primeiro aspecto não há quaisquer distinções possíveis entre os ouvintes, que neste caso se encontrariam todos condicionados apenas a reagirem passivamente dentro dos limites da indiferenciação instintiva diante da manifestação imediata por eles considerada inquestionável e inultrapassável. Ao passo que, no segundo aspecto, referente a uma transcendência de si da música, então dissolvente das determinações imediatas, há a apresentação da mediação como realidade universal que modifica, dificulta e fundamenta as relações humanas, então promotoras de singularidades e de individualidades autônomas e autênticas, resultantes deste processo de negação de si do homem, correlato daquele da transcendência da música. Nesses termos, Adorno acrescenta que "toda vez que a paz musical se apresenta perturbada por excitações bacânticas, pode-se falar da decadência do gosto" $(1999$, p. 65). Relacionada ao apego à mitologia, sobretudo ao mito de Baco ou Dionísio, a decadência do gosto se revela como uma inconsciência de si do eu, uma identidade ainda em formação, ou uma perda violenta da identidade que, em sua embriaguez e delírios báquicos, se entrega arrebatada e submissa às forças naturais mais arcaicas e obscenas, que o eu, entendendo-as como possuidoras da sua própria identidade, procura mimetizá-las, deste modo, naturalizandose inteiramente, isto é, tornando-se num nada ou em ninguém. Restrito aos seus aspectos naturais - e mitológicos - o gosto decadente é o que ainda não se esclareceu suficientemente, e ainda não adquiriu a consciência de si mesmo, o que também significa dizer que, naturalizado, o gosto é sem sujeito, sem eu. Nestes termos, em que pese as condições da mencionada decadência, podemos afirmar que "ninguém tem gosto", já que eu não sou sujeito do meu gosto, como se outro que eu não sou gostasse por mim mantendo-me sempre afastado de mim mesmo.

A decadência do gosto refere-se, igualmente, "a função disciplinadora da música" valorizada, por exemplo, por Platão, porém, vista por Adorno como uma teoria que leva "a obedecer cegamente à moda 
musical”. O grego, que acreditava na correlação entre alma e harmonia, também concedeu espaço, na sua filosofia, para a defesa da correlação metafísica entre as formas musicais não fenomênicas e os ethoi, vendo na música, como expressão da estrutura cósmica, um importante expediente pedagógico de formação das virtudes das almas, conformando-as a uma harmonia preestabelecida, imodificável e incorruptível - metafísica ou política - e afastando-as da hýbris e dos vícios corruptíveis das mudanças sensíveis ${ }^{4}$. Essa concepção moral-pedagógica da música, fundamentada numa metafísica da harmonia apenas acessível através de uma intuição noética, foi um elemento disciplinador em prol da coesão excludente da coletividade na Polis, cuja harmonia requeria a centralização de um governo que era o início e o fim das relações entre os privilegiados cidadãos, que deviam-lhe, pois, obedecer cegamente, como a um pai ideal. Era este que, despersonalizando-os, definia os gostos dos seus filhos, condicionando-os através de uma imutabilidade da escuta da identidade do sempre-o-mesmo conceitual e estatal.

Escutar diferentemente o diferente, eis o que seria individualização ou a gênese do sujeito em seu próprio gosto enquanto consciência de si mesmo, das suas qualidades distintivas subjetivas e não mais naturais e exteriores. Só se alcança esta individualidade do gosto quando entendemos que, para além da sua passividade e obediência cega e instintiva que nos insere no fluxo impessoal da inércia, ele exige-nos, inapelavelmente, o esforço para compreendermos e conhecermos, como se, nestes termos, construíssemos (quais verdadeiros sujeitos autônomos não determinados por nossos gostos), aquilo de que gostamos sem regras prévias às quais deveríamos nos adequar. Entretanto, neste sentido, e analisando entediado

\footnotetext{
4 "Nesse aspecto, Platão se aproxima das concepções pitagóricas sobre a música, pois a harmonia da música absorve a harmonia do universo (cosmos)" (TOMÁS, 2005, p. 22), e neste sentido, mousiké, associada ao verbo manthanein (aprender), é uma harmonia que educa o espírito corrigindo os seus desequilíbrios físicos. "Isso ocorre, porque esta harmonia cósmica se reflete na harmonia da própria música, na organização dos sons: quando esta é ouvida, atua diretamente em nosso corpo e espírito e nos reequilibra; por outro lado, a música enquanto conceito, como instrumento do pensamento e do conhecimento, se relaciona à essência do universo, pois a harmonia representa a ordem reinante no cosmos" (TOMÁS, 2005, p. 23).
} 
e sem esperança a sombria consciência musical contemporânea das massas, Adorno admite que "o próprio conceito de gosto está ultrapassado", de tal modo que, buscando uma orientação urgente, a "arte responsável" já o analisa, secamente e evitando promessas, de acordo com os critérios do conhecimento: "o lógico e o ilógico, o verdadeiro e o falso".

De resto, já não há campo para escolha; nem sequer se coloca mais o problema, e ninguém exige que os cânones da convenção sejam subjetivamente justificados; a existência do próprio indivíduo, que poderia fundamentar tal gosto, tornou-se tão problemática quanto, no pólo oposto, o direito à liberdade de uma escolha, que o indivíduo simplesmente não consegue mais viver empiricamente (ADORNO, 1999, p. 66).

A decadência do gosto está relacionada, fundamentalmente, à impossibilidade empírica da liberdade, o que se traduz, nocivamente, numa debilitação tamanha da existência do indivíduo, que deste lhe foi retirada a capacidade de ser o fundamento do seu gosto, e com isto, sem saber encontrar em si, livremente, as condições interiores pelas quais ele defende e justifica a particularidade do seu gosto, o indivíduo se encontra diluído e moldado pela ausência coercitiva de escolhas que faz da liberdade uma realidade metafísica unicamente acessível através do sonho dos indivíduos. Sonhar com a liberdade, que eles não têm a permissão de viver empiricamente, é o que resta aos indivíduos que, assim de modo inexorável, existem com esta mesma fragilidade violentamente quimérica de perderem-se enquanto fundamento das suas escolhas e dos seus gostos. Não poder escolher e gostar sem fundamento algum resulta, finalmente, em retirar da subjetividade - como instância de resistência e de preservação do que nos é inalienável - a dignidade dos seus critérios qualitativos de livre julgamento, então deformada, apagada e reduzida a uma identificação mimética com o ambiente social naturalizado e estabilizado em aparências necessárias que reprimem a espontaneidade e a consciência de si do gosto e, mantendo o alienante amorfismo da inconsciência, sustentam o estabelecimento totalitário de valores padronizados que levam a uma generalização superficial e impessoal de uma identidade não empírica. 
Se a liberdade não é vivida empiricamente, "o gostar e o não gostar já não correspondem ao estado real", mas, sendo determinados por necessidades ilusórias e artificiais que desviam o indivíduo para uma identificação mecânica com a exterioridade de si mesmo, o gostar e o não gostar constituem-se como elementos de uma falsa experiência social, ao passo que, para Adorno, o esclarecimento deveria estar presente já no gosto que, portanto, nos mostraria a distinção entre a aparência e a realidade do social como processo complexo caracterizado pelas possibilidades de tomar forma e de mudanças dialéticas e qualitativas entre as suas formas abertas. Esta verdadeira administração do gostar e do não gostar - então industrializados e controlados como produtos sem autores - nos afasta da "própria coisa" de que gostamos ou não, tornando a sua presença a nós desnecessária e, deste modo, basta que a ela - apresentada como um dado originário, acabado e inquestionável - tenhamos acesso através de uma totalidade quantitativa e abstrata para a qual nossa própria presença é igualmente desnecessária. Ou seja, não podemos fazer-nos presentes, concreta e qualitativamente, através dos nossos gostos. Conforme essa industrialização controladora do gosto - assim padronizado e oferecido como algo que espontaneamente não se tem e que por isto deve ser artificialmente consumido - o reconhecimento "por todos" se torna o critério de julgamento do sucesso de uma música, cuja natureza mercadológica (e função ideológica) lhe determina uma acessibilidade quantitativa, pelo que ela deve ser simples, ingênua, infantil, e não requerer do ouvinte que este utilize suas faculdades mentais emancipadoras, pois, assim, o ouvinte se tornaria sujeito do que ele recebe auditivamente, saindo da mera reprodução não individualizante da heteronomia que não lhe permitia reconhecer-se um padecente submisso à falsidade das promessas sociais de felicidade que apenas mantinham-no em sua passividade sem predileções próprias. É preciso que sejamos sujeitos ou indivíduos inclusive em nossa receptividade, é preciso que, nesta, tenhamos escolha ou que já nesta dimensão possamos ser livres.

No entanto, diante da industrialização adulterante e impositiva do comportamento valorativo e da mercadorização que padroniza as músicas - serializando tanto a sua produção quanto a sua recepção - o indivíduo “já não consegue subtrair-se ao jugo da opinião pública, nem tampouco 
pode decidir com liberdade quanto ao que lhe é apresentado" (ADORNO, 1999, p. 66): uma música exterior a si mesma. As condições e valores desta música, não sendo intrinsecamente musicais e estéticos, permitemnos compreendê-la como uma mera reprodução das miseráveis condições materiais (e humanas) que lhe servem de base, e por extensão, como um instrumento destinado à integração adaptativa do indivíduo ou à defesa da coesão e da harmonia social. Exterior a si mesma, inexpressiva e amorfa, sem valor intrínseco próprio como a arte autônoma, autêntica e verdadeira, a música não nos diz nada, sem sentido, ela não nos apresenta nada de diferente, de estranho e de outro, e é isto que é oferecido à nossa audição, então conformada e condicionada por essa facilidade e conforto de não se deparar e não se abrir ao inaudível para além do mutismo coletivo, exterior, inautêntico e totalitário. Não ouvimos nada quando ouvimos esta música ligeira transformada em mercadoria destinada ao consumo imediato, passageiro e instintivo. Esta padronização musical - sustentada por uma produção industrial e em série da audição, então condicionada e exterior a si mesma - é a promoção de um mutismo generalizado como um processo de integração e de proteção da harmonia da coletividade que, ao se estruturar negando e banindo dos seus domínios o inaudívelnão-idêntico, se pretende inquestionável em sua sempre-igualdade a si mesma. $\mathrm{O}$ mutismo da música ligeira é a sua própria repetibilidade nãoestética enquanto produto sempre-igual a si mesmo, inteiramente estéril e improfícuo. Essa música não tem nada de audível, pois, o seu sempreigual totalitariamente absolutizado através das suas monótonas repetições, ao levar a audição, então destituída de memória, à impessoalidade de um funcionamento mecânico e automático, resulta numa perda patológica da audibilidade essencialmente intrínseca à própria música, de um lado, e também ao homem, de outro; o que nos permite, ainda que atônitos, a nos indagar pela possibilidade de existir uma música não musical. Esta seria uma música que, destituída da temporalidade estética, não seria mais audível, e sim, visível, tornada imagem estática no espaço em que os acontecimentos idênticos se repetem e se negam afirmando a descontinuidade entre a memória e a esperança do indivíduo de ser de outro jeito da sua identidade fenomênica simbolicamente codificada. Ao ceder a esta adulteração da audição e se tornar imagem não audível, a música adquire os limites do 
espaço que a separa dela mesma, seduz-lhe com a promessa de um falso e ruim infinito e lhe retira, deste modo, sua capacidade crítica de não ser idêntica para si mesma completamente e de nesta reconciliação consigo mesma intimamente cúmplice do estranho e do desaparecimento, resistir a ser um tempo-imagem desprovido do "movimento dinâmico de autoanulação da identidade" (SAFATLE, 2007, p. 385) como uma crítica ao fetichismo ${ }^{5}$. Safatle (2007, p. 383-404) analisa e descreve o fetichismo como um processo de civilização da audição, então tonal e matematicamente protegida da tragicidade da conciliação consigo mesma sem identidade: como um impulso inconsciente e um desejo insaciável de amorfo e do que é resto deixado pelo processo de dominação conceitual e científica do material musical. Safatle lembra que este material, mesmo assim gasto e arruinado, conserva certa estranheidade não entificada que reclama ser revisitada pelo compositor inelutavelmente seduzido pelas ruínas do que escapou do ascetismo civilizatório que compreendeu o prazer tendo a harmonia, a espetaculosidade da aparência e o sucesso quantitativo como critérios.

A música ligeira - enxugada quase aos instantes pobres dos seus detalhes soltos e aritmeticamente repetidos - proporciona, tão somente, "entretenimento, atrativo e prazer, porém, apenas para ao mesmo tempo recusar os valores que concede"(ADORNO, 1999, p. 66). Ou seja, do mesmo modo que a música ligeira é a mortificação da audibilidade - impedindo que, na sua esfera, a audição alcance a consciência de si mesma - ela é a recusa do que ela proporciona: seu entretenimento não é entretenimento, seu atrativo não é atrativo, seu prazer não é prazer ${ }^{6}$. Assim, diante deste

5 Como dissolução da pré-codificação simbólica, essa autoanulação é reconciliação vista como protesto e saída da opressão da civilização conformada por um desejo de beleza apenas visível e cujo aparecer - em seu falso brilho que se furta ao dissonante horrível e ao sombrio - é uma imagem desencantada e sem vida justamente porque se quis sem as cinzas da audibilidade pré-linguística do que não é mais aparência, do que morto é salvação (CHIARELLO, 2006, p. 151-175), e nesta obscuridade repousa inalcançável pelas luzes de néon com imemoriais ressonâncias apolíneas.

6 E assim o social, bastante teatralizado, sobrevive envenenando-se a si mesmo, pois, ao instituir o Mesmo como responsável por sua coesão ocorre a aniquilação da singularidade individual e da diferença através da recusa e da adulteração do prazer, então regido pelo "ideal paranóico do caráter sado-masoquista". Contra tais excessos, "Adorno mostra na 
ilusionismo auditivo, somos condicionados a aceitar, quais crianças dóceis sem vontade própria, o que se nos é recusado, porque é através do que nos é recusado que as nossas relações sociais, em toda a sua amplitude, se estabelecem e se mantém inofensivas, não para os seus atores, mas, para os seus personagens. Em uma palavra, nos relacionamos porque somos recusados, e ainda tomamos isto como uma diversão, quando, na verdade, fazendo suas as palavras de Aldous Huxley, Adorno indaga: "quem ainda se diverte realmente hoje num lugar de diversão", se em qualquer lugar, nos dias atuais, somos levados a nos divertir recusando-nos a nós mesmos?

Com o mesmo direito poder-se-ia perguntar: para quem a música de entretenimento serve ainda como entretenimento? Ao invés de entreter, parece que tal música contribui ainda mais para o emudecimento dos homens, para a morte da linguagem como expressão, para a incapacidade de comunicação. A música de entretenimento preenche os vazios do silêncio que se instalam entre as pessoas deformadas pelo medo, pelo cansaço e pela docilidade de escravos sem exigências (ADORNO, 1999, p. 67).

A música que se transforma em entretenimento cobra um preço dos seus fiéis seguidores que não se restringe apenas à sua natureza econômica, pois, ela se alimenta do emudecimento não silencioso dos homens, levando-os a se relacionarem através de uma linguagem morta, inexpressiva e reduzida a vazios sonoramente ruidosos em seus signos e em suas significações gastas e empobrecidas. Sem poder escolher, diante desta música, o homem não tem voz, embora ele fale, sem com isto, entretanto, ser considerado e respeitado como o sujeito da sua linguagem, posto que, através desta, ele não mais se diz expressando o irrecusável em relação ao qual há a verdadeira comunicação. Para se constituir, a música ligeira prescinde da expressividade e da comunicabilidade, não apenas porque ela

Dialética Negativa que a saída acha-se na natureza, no 'impulso arcaico anterior ao ego', capaz de desmantelar o delírio da identidade absoluta e restituir a diferença, o não-idêntico, ao seio da cultura" (BARRETO, 1992, p. 53). O que requer a dialetização do material a fim de responder-lhe às suas exigências temporais concretas que se constituem como instância de resistência à assimilação destrutiva pelo homogêneo, que nutrindo-se da sua própria paranóia, se auto-mimetiza. 
é incapaz de apreender e de elaborar a musicalidade não-figurativa da voz humana ou a audibilidade das palavras, mas também, porque assim ela esvazia o silêncio de seu elemento crítico, dialético, e formador, excluindo o inaudível irrecusável da esfera do mutismo do entretenimento.

A exploração da musicalidade não-figurativa da voz e a pergunta pela essência sonora-audível da palavra, que a princípio soaram como um anarquismo discursivo, foi o que fez Schoenberg, levando-o à invenção do Sprechgesang (canto-fala, fala cantada) que sendo também a recuperação da extensão temporal das estruturas musicais, asseguraria a lógica e a unidade orgânicas da obra em sua coerência especificamente estética irredutível à industrialização do mutismo (MENEZES, 2002, p. 137-165). O irrecusável audível não era propriamente a voz ou a palavra de um discurso unidirecional e ingênuo com um fim efetivo e previsível desde o início. Quanto a Berg (MENEZES, 2002, p. 167-236), a expressividade e a comunicabilidade da música requerem uma fenomenologia da escuta que reconheça os seus limites absorvendo o silêncio como o repouso modificante do som e nos conduza, assim, para uma metalinguagem especulativa sem referencialidade previsível e que então liberta a leitura e a escuta que, deste modo apresentando-se capazes de escapar do rigoroso controle matemático do som próprio da série-de-base, prenunciam os limites congênitos e crônicos do dodecafonismo e profetizam uma audibilidade do não número e uma musicalidade de manifestações místicas não industrializáveis. Baseando-se em Webern como o teórico das condições de inteligibilidade da comunicação musical, Ricardo Barbosa considera a música como linguagem cuja racionalidade comunicativa se assenta na noção weberniana de apreensibilidade enquanto uma lei a priori e transcendental que se constitui como o princípio supremo de apresentação pragmática e linguística dos pensamentos musicais diferentes dos verbais padronizados pela gramática do cotidiano. Aapreensibilidade é um universal pragmático que fundamenta as pretensões de validade e de racionalidade especificamente estéticas da música. O que constitui, desde a base, a prática comunicativa é, por sua vez, inaudito, porque em sua coerência e novidade a-gramaticais é julgado arbitrário e anárquico. É preciso que haja obras e só podemos falar da existência de obras quando elas nos mostram o seu próprio enraizamento na natureza material então recuperada como 
constitutiva da legalidade transfenomenal do sonoro. A apreensibilidade é superação sintática e semântica da linguagem compartilhada, tal como foram as obras de Schoenberg e de Webern, "idealmente destinadas a todos como o horizonte contrafático do reconhecimento público de sua pretensão de validade estética" (BARBOSA, 2007, p. 29), e acabaram por se configurar, devido a tanto respeito e exigência da audição que deveria se debruçar sobre o inaudito-não-mudo, como peças para ninguém, "porque aparentemente impenetráveis, inapreensíveis". Diante disto, para Barbosa, "o problema pragmático que subjaz então a toda discussão sobre a apreensibilidade é o da audição - ou, mais precisamente, o da escuta musical. Em que consiste uma audição bem sucedida? (BARBOSA, 2007, p. 30).

De acordo com essas condições de uma racionalidade comunicativa, de uma verdadeira comunicação e da escuta enquanto pensar com os ouvidos, consideramos que "se ninguém mais é capaz de falar realmente, é óbvio também que já ninguém é capaz de ouvir" (ADORNO, 1999, p. 67). Tanto através do que se fala quanto através do que se ouve o que ocorre é um afastamento, alienante e repressivo, da realidade, cujo contato é emocionalmente e psicologicamente doloroso e angustiante para os "eus" domesticados e providencialmente enfraquecidos pelos estereótipos coletivos, inexpressivos e não-musicais. Essa domesticação é própria do processo civilizatório que se impõe como uma espécie de ditadura da autoconservação da identidade do indivíduo que fragilizado se rende e se autodomina e assim se castra na generalidade, diante da qual, em proveito da mera subsistência do seu eu, ele tem a identidade de ninguém, inteiramente encantado e hipnotizado pela música muda que não lhe ameaça tal como o canto sedutor das sereias, canto cujo preço é a própria identidade simbolicamente codificada e estabilizada através da falsificação civilizatória da mimesis, tornada possível pela exploração e manipulação da vida pulsional dos indivíduos ${ }^{7}$. Mantendo-se com essa falsificação que incide sobre as pulsões dos indivíduos, a civilização - tornada indústria

7 Diante da totalidade social que camufla sua irreconciliação defendendo a mimesis como conservação da identidade imposta, "o comportamento mimético autêntico tem lugar, para Adorno, num estado de reconciliação com a morte, de aceitação da dissolução da identidade, só ela capaz de acolher uma identidade alheia" (CHIARELLO, 2006, p. 29). 
cultural administrada-manipula os seus "clientes" para que estes absorvam, passivamente, "conteúdos de reforço ideológico do sistema, acreditando ainda estarem satisfazendo sua legítima necessidade de diversão, lazer e cultura" (DUARTE, 1997, p. 57). Na verdade, a programação que lhes é coercitivamente oferecida foi elaborada a partir da interferência na economia psíquica das pessoas que já e então se recusam mimeticamente encontrando-se desindividualizadas ao máximo, ou seja, irracionalmente animalizadas, na medida em que para se autodefenderem, e agindo de modo irrefletido e mecânico, buscam não apenas uma semelhança com o ambiente simbólico que os nega, como também um determinado modelo, uma espécie de herói mitológico, "ou até mesmo o Führer" (DUARTE, 1997, p. 59). Eis alguns resultados do processo de massificação ilusionista da nossa audição. De uma forma ou de outra, mas sempre com o nosso consentimento, o ilusionismo invadiu a nossa capacidade de falar e a nossa capacidade de audição, fazendo com que nós nos recusemos a nós mesmos quando falamos e quando ouvimos e, portanto, somos ninguém em nossa fala e somos ninguém em nossa audição. Tamanha despersonalização culmina em uma verdadeira esquizofrenia auditiva generalizada, sob a égide da qual, não apenas o sujeito não se individualiza em sua audição, mas, a própria audição não é mais atenção a si mesma, encontrando-se, deste modo, frágil e susceptível ao mutismo das ilusões e a aceitar a redução da música aos anúncios publicitários, que requerem a sobredita desatenção da audição, alcançada, entre outros meios, através desta destituição de si da música. Ao passo que, o que há de audível-não-mudo na música, o que constitui a sua audibilidade essencial, aquilo que nela exige a atenção a si da audição e exige a nossa individualidade, é a própria música, compreensível em si e a partir de si mesma.

O referido esquizofrênico "encantamento dos sentidos", enquanto um processo de degeneração da audição, é um elemento intrínseco a um estado de decadência do gosto. Estamos diante de uma mitologia da audição cuja capacidade encantatória (e também narcótica) força-nos a regredirmos, e nos mantém na infantilidade dos nossos sentidos, então submissos a ídolos quaisquer idealmente deificados. Os ídolos - mesmo os culturalmente fabricados - tendo em si mesmos um forte caráter mitológico pelo qual se impõem totalitariamente suas pessoas, se formam 
e se mantém oferecendo o que não sacia e disto também se alimentando, a saber, aquele encantamento que impede a diferenciação qualitativa da consciência através do livre prazer dos sentidos. Tal depreciação resulta numa liquidação da subjetividade na música que, sem este elemento expressivo e objetivamente instrumentalizada, apresenta-se desumanizada. Nesses termos, nem sempre a libertação do prazer entendida como salvaguarda e cultivo da subjetividade significou uma entrega derrotista à coação autoritária do entretenimento que mercadorizou o próprio espírito. Em sua dimensão fundamental, como uma etapa necessária do processo dialético de fortalecimento e de reencontro consigo do espírito, o prazer nem sempre quis dizer falta de liberdade e mera susceptibilidade passiva ao fluxo inalterável, anônimo e inerte de uma sociedade ideológica construída por uma razão cuja autonomia conservadora rejeita qualquer elemento revolucionário que lhe questiona e resiste, como a subjetividade e o prazer dos seus sentidos.

Todavia, o que então se emancipa da lei formal não são mais impulsos produtivos que se opõem às convenções. $\mathrm{O}$ encanto, a subjetividade e a profanação - os velhos adversários da alienação coisificante - sucumbem precisamente a ela. Os tradicionais fermentos antimitológicos da música conjuram, na era do capitalismo, contra a liberdade, contra esta mesma liberdade que havia sido outrora a causa de sua proibição, devido às afinidades que os uniam a ela (ADORNO, 1999, p. 69).

Assim se consolida um processo de coisificação que torna tão imperiosas as convenções que se coloca a proibição como um elemento da emancipação. Deste modo, não há liberdade fora das convenções cujos limites, tão objetivados, apresentam-se como as determinações de uma Coisa sempre adiante e acima das cabeças. Esse processo retira do prazer a sua dialética intrínseca, rebelde, e o desloca para a aparência e para o momento efêmero de um vazio corrosivo. Assim, adulterado e domesticado, o prazer também se torna uma convenção, ele se torna prazer de uma coisa completamente estereotipado e transformado num meio de auto-castração sadomazoquista e patológica da subjetividade. 
Absorvido pelos momentos efêmeros que através da sua saciedade ilusória se infinitizam como objetos de prazer, e desta maneira mostram a falsidade da variedade musical, "o ouvinte se converte em simples comprador e consumidor passivo" do próprio todo pré-fabricado com a exclusão das possibilidades de ser de outro modo. As convenções, sem durabilidade e temporalmente improfícuas, são mentirosas em suas promessas que, antes, negam a esperança como um movimento ativo e crítico de modificação qualitativa da realidade pré-codificada. Essa codificação prévia que cega a vista, então encantada, se impõe como o sempre-o-mesmo que assegura o sucesso das músicas que, temporalmente indiferenciadas entre si, levam à indiferenciação dos ouvintes, nos quais já não se encontra o impulso à insubordinação e à rebeldia constitutivo da correlação entre prazer e esperança.

Sair do sempre-o-mesmo que estabelece e mantém a indiferenciação requer não apenas recuperar o tempo, mas também, sua transcendência de si pela qual ele se torna uma duração indeterminada e irredutível ao espaço que homogeneíza. Essa dupla recuperação se dá através da compreensão de que a temporalidade específica e intrínseca da música é abstraível do tempo em que ela se realiza, apenas materialmente, no som, que, conforme Eggebrecht, "não só necessita de tempo no seu difundir-se, mas ele próprio é o ressoar do tempo" (2009, p. 139) que se prescinde enquanto conteúdo próprio para ser forma não fenomênica da música, então estética e audível, na medida em que ela se constitui como existência para si do tempo ${ }^{8}$. Se, para Eggebrecht, "o tempo é a dimensão mais existencial do ser humano" e "de todas as realidades a mais real", aquela que permite ao Eu identificarse, mais do que isso e, entretanto, "o tempo musical é, em relação a esta realidade mais real, a anti-realidade mais real", ou seja, a música como uma existência no tempo ou o tempo musical, é "o protótipo da irrupção do tempo a partir do tempo, o acolhimento de tudo o que existe nesta subtração ao tempo: é libertação do tempo" (EGGEBRECHT, 2009, p. 141;

\footnotetext{
8 Sobre a relação entre música e tempo é oportuno mencionarmos que, concluindo a sua breve exposição técnica e filosófica acerca da história do termo harmonia na Grécia antiga, Flo Menezes afirma que a harmonia - sinônimo de música - é um transcorrer temporal das relações simultâneas complexificadas sequencialmente. "E tudo isto torna-se possível através desse elemento essencial a toda música: o tempo" (MENEZES, 2002, p. 402).
} 
grifos nossos) cronológico, não estético, e marcado pela descontinuidade e repetibilidade espacial dos seus momentos homogêneos que regem a massificação e estabilizam a harmonia existente, e assim, o tempo limitado e repetível não nos apresenta nada para esperarmos, mecanizando o nosso prazer. Este tempo-coisa-e-imagem se nos apresenta como o mutismo social e musical.

A manutenção da harmonia existente - à qual a música de massa se adapta reproduzindo-a em si como sua tonalidade - se faz por meio do impedimento do não-idêntico e da ascese da dissonância, o que resulta numa estética reacionária, deficiente e pobre, cujos produtos são o culinariamente gostoso e o que deve ser consumido imediatamente, pois se estraga tão logo se esfria, deixando de ser um hit possuidor de um calor que não aquece, não conforta e não reúne verdadeiramente. Todas as promessas de felicidade da arte revelaram-se falsas, e com isso a própria arte perdeu a capacidade e se desobrigou de mostrar a infelicidade da qual se alimenta a harmonia existente. "Toda arte ligeira e agradável tornou-se mera aparência e ilusão", afirma Adorno, para quem "a promesse du bonheur - foi assim que uma vez se definiu a arte - já não se encontra em lugar algum, a não ser onde a pessoa tira a máscara da falsa felicidade" (1999, p. 71). O agradável imediato não pode definir ultimamente a felicidade, que é verdadeira apenas se ela reconhece o sofrimento em sua constituição sempre demorada e que exige o aprendizado emancipador da esperança. Adorno reclama um prazer estético que vai além da presença imediata que se pode corporalmente tocar, uma vez que, "somente se mantém fidelidade à possibilidade do prazer onde cessa a mera aparência”. A verdadeira ascese não se define, tal como o prazer da aparência, "pela negação e rejeição do prazer no próprio prazer", deste modo banalizando a cultura então transformada em bens de consumo que entretém.

A cultura, tornando-se apenas o que pode ser comprado, encontrase determinada pela lei mercadológica da oferta e da procura que dela exclui uma grande massa de indivíduos que, produzindo a negação e a rejeição do prazer no próprio prazer, mantém a sua alienação. Não há espaço para a individualização, já que os indivíduos são forçados a se adaptarem aos padrões gerais. Nestas condições, "a liquidação do indivíduo constitui o sinal característico da nova época musical em que vivemos" 
(ADORNO, 1999, p. 73). Nesta época, há a troca da individualidade pelo que se consome. $\mathrm{O}$ valor da individualidade está na sua possibilidade de ser trocada, expondo-se a si mesma como uma mercadoria repetidamente se expõe, recusando lutar pelo seu desejo de reconhecimento, pois, antes de correr o risco vital inerente a este, é preferível ceder à mimesis com a finalidade de autodefesa e autoconservação. E a própria individualidade dos ídolos dos fãs das músicas-produtos não pode ser demasiadamente elevada para os seus seguidores, uma vez que estes, sem revelações sobrenaturais e sem pretender romper com suas precárias condições de existência buscando melhorá-las qualitativamente, devem ser capazes de imitar os seus ídolos, reificando-os ao mesmo tempo como obstáculos antes que como estímulos.

O princípio do "estrelato" tornou-se totalitário. As reações dos ouvintes parecem desvincular-se da relação com o consumo da música e dirigir-se diretamente ao sucesso acumulado, o qual, por sua vez, não pode ser suficientemente explicado pela espontaneidade da audição mas, antes, parece comandado pelos editores, magnatas do cinema e senhores do rádio (ADORNO, 1999, p. 74).

As estrelas que se pretendem eternas - cujo brilho não vem e não se alimenta do desaparecimento do seu corpo celeste - não estão no céu, mas, ainda assim decaídas, continuam sendo referências para os homens, então, com os pés bem presos ao chão dos caminhos sem descobertas e sem surpresas pelos quais são confortavelmente conduzidos para lugar algum a não ser onde já se encontram. O brilho destas estrelas não é delas, artificialmente construído, ele dissimula sua falsidade não apenas impedindo que se veja o que o desnudaria, mas também, coagindo a visão a acreditar-se espontânea. Esse processo de desqualificação "perpetua-se e termina num círculo vicioso fatal", como compreende Adorno porque, deste modo, "o mais conhecido é o mais famoso, e tem mais sucesso", por extensão, sendo "gravado e ouvido sempre mais, e com isto se torna cada vez mais conhecido" (ADORNO, 1999, p. 75). Eis a recusa, generalizada e compartilhada, do desaparecimento e da alteridade. A condição do "mais conhecido" ser sucesso é ele não ser tão bem conhecido, isto é, o seu mais 
é quantitativo e não qualitativo. Nesta linha de raciocínio, o que é mais comprado é o mais distante, cuja estranheidade já se nos tornou familiar. Quando compramos a música familiar mantemos toda essa distância definidora do sucesso, então fabricado pelos consumidores pré-formados, que se acreditam próximos do que fabricam, porque "a aparência de proximidade e de imediatidade é tão real quanto é inexorável a pressão do valor de troca" (ADORNO, 1999, p. 78) que se impõe dissolvendo as relações entre os indivíduos e o que se encontra além do espesso véu da familiaridade. Reinante nesta ordem, o valor de troca define o caráter fetichista da música: "os efeitos que se dirigem para o valor de troca criam a aparência do imediato, e a falta de relação com o objeto ao mesmo tempo desmente tal aparência. Esta carência de relação baseia-se no caráter abstrato do valor de troca" (ADORNO, 1999, p. 79). O valor de troca é próprio de um imediato que não aparece como tal, incrustando-se em algo que parece se apresentar sempre próximo, mas com o que não se relaciona: as próprias obras convencionalmente exteriorizadas, tornadas coisas aceitas com paixão, que requerem este apaixonar-se pelo que não se tem como um bem cultural ${ }^{9}$.

$\mathrm{O}$ valor de troca transforma tudo em produtos cujo consumo não significa relação. A relação não vigora no que se paga por ela e, neste sentido, ela escapa a pré-determinações quaisquer, assim como às leis coercitivas que regem o mercado padronizante. $\mathrm{O}$ valor de troca é o último ídolo do consumidor que não se reconhece e se nega em seu comportamento idólatra de fabricação das suas ilusões, com as quais ele tem manipuladas umas e impostas outras necessidades. Ao cultuar o valor de troca, o indivíduo sequer se relaciona consigo mesmo, e com isso não dispõe de meios de resistir à manipulação das suas capacidades e qualidades - inclusive das que lhe eram inalienáveis e um reduto contra o totalitarismo da organização técnica e funcional - elas mesmas absorvidas pelo mercado, tanto econômico quanto cultural, como produtos cujo valor consiste em sua permutabilidade previamente acordada em conformidade

9 Reforçam-se reciprocamente o valor de troca e o fetichismo, que transformam as obras, violadas violentamente, em bens culturais depravados. Nas obras que assim se transformam não há espaço para a inocência, visto que, "o consumo, destituído de relação, faz com que se corrompam" em coisas repetidas. 
com os critérios do próprio mercado, que então se salvaguarda. Assim se configura o valor de uso do valor de troca, que se impõe tão eficazmente que não se percebe que ele está sendo usado, deixando-nos a ilusão de que nos relacionamos entre nós e com o que consumimos, a ilusão de que consumimos mercadorias diferentes e, deste modo, nos distinguimos uns dos outros. Na verdade, o qualitativamente distinto não é tolerável pelo princípio de troca que, estruturando-se sobre o ideal burguês da igualdade, reduz os indivíduos não idênticos a uma identidade genérica intercambiável, cuja materialidade, indiferente ao tempo, se define e se conserva recusando a transformação e a não identidade como sua tendência intrínseca. Para dissolver tal princípio de identidade pré-codificada e para superar esta identidade material prévia e acabada que se entrega sem resistência, é preciso conceber uma música que, ao ser capaz de revelar a resistência (a não dentidade temporal) constitutiva da identidade material fenomênica, se torne "um modelo de uma identidade outra, de uma identidade que é liberdade, uma identidade completamente distinta da identidade que perpassa a sociedade, aquela da forma-equivalente e do sempre-igual" (WAIZBORT, 1992, p. 39).

O que o ouvinte idolatra é "o dinheiro que ele mesmo gastou pela entrada num concerto de Toscanini", e não a qualidade intrínseca à música em sua esfera de legalidade própria, e é esta troca, o seu "objeto de prazer". Há prazer apenas no uso generalizado e padronizado da permutabilidade que corrompe e substitui as relações juntamente com os seus atores humanos. Ao passo que "todo prazer que se emancipa do valor de troca assume traços subversivos" (ADORNO, 1999, p. 79), pois, este prazer rompe com a objetividade fantasmática e teológica dos puros símbolos reificados e adorados pelo fetichista também responsável pela onipotência da produção que absorve, diluindo-o, o seu eu masoquista.

A renúncia à individualidade que se amolda à regularidade rotineira daquilo que tem sucesso, bem como o fazer o que todos fazem, seguemse do fato básico de que a produção padronizada dos bens de consumo oferece praticamente os mesmos produtos a todo cidadão. Por outra parte, a necessidade, imposta pelas leis do mercado, de ocultar tal equação conduz à manipulação do gosto e à aparência individual da 
cultura oficial, a qual forçosamente aumenta na proporção em que se agiganta o processo de liquidação do indivíduo (ADORNO, 1999, p. $80)$.

A produção padronizada leva à repetibilidade das individualidades renunciadas e, portanto, entre si indistintas, mas todas narcotizadas, psicastênicas e esquizofrênicas. Ao ser mero consumidor do que assim é produzido, eu me renuncio e, em última instância, isto é um consumir-se a si mesmo com quem há muito já não se relaciona. Em todo caso, parece ser satisfatório fazer o que todos fazem, rotineiramente, então se sentindo inserido na regularidade do mecanismo produtivo que lhe protege da solidão, do isolamento, da dor e da angústia de estar próximo de si mesmo sem artifícios quaisquer. A diferença não pode ser produzida e não se pode consumir diferentemente, embora acreditemos, em regime de fascinação e de engodo, nas novidades que são, no entanto, apenas artificiais. Nestas condições, da estereotipização dos produtos, segue-se a estereotipização dos indivíduos, e tal processo ideológico de produção artificial do reino da positividade culmina no antagonismo travestido entre a cultura e o indivíduo que tem seu gosto manipulado para aceitar, como se diz "sem compromissos", a igualdade dos produtos oferecidos, que mascara seu consumo universalmente obrigatório. Até através do modo de consumo inquestionável, disciplinador, combatente da arbitrariedade e da anarquia - se faz presente o universal em detrimento da livre escolha do indivíduo.

Submetido à invariância das repetições contínuas da música, o indivíduo ouvinte se acredita "proprietário" da música, por sua vez, transformada em uma coisa que se possui, em uma mercadoria que se pode ter comprando-a, sem com ela se relacionar, intrinsecamente, no que ela tem de irredutível e de resistente à alienação da audição. Em outros termos, qualquer um julga-se proprietário da música porque esta se oferece repetidamente e indistintamente em vias públicas como uma coisa exposta, sem vergonha alguma, para mero usufruto alienante ${ }^{10}$.

\footnotetext{
${ }^{10}$ Diante disto, para Adorno, as escolhas se reduzem a "ou entrar docilmente na engrenagem do maquinismo - mesmo que apenas diante do alto-falante no sábado à tarde -, ou aceitar essa pornografia musical que é fabricada para satisfazer às supostas ou reais necessidades das massas" (1999, p. 85).
} 
"O processo de coisificação radical produz a sua própria aparência de imediatidade e intimidade" (ADORNO, 1999, p. 84), e assim camuflando-se, a coisa não aparece como coisa, ou seja, como algo exterior, não familiar e agressivamente proibidor. Quando bem considerado, o imediatismo coisista é sempre afastamento, e os atores ou proletários culturais, através das suas imagens produzidas ou da transformação das suas individualidades em marcas comerciais, são os porta-bandeiras de um esvaziamento da intimidade, muito embora o público, ao assistir a certos programas de televisão, ao ler certas revistas ou ao ouvir e cantarolar suas músicas, acredita-se íntimo dos seus ídolos, tal como o fiel acreditase íntimo de Deus ao ir à igreja, ao ler a bíblia ou em suas monótonas ladainhas de resignação. A coisa encantada - a música-imagem - mantém todos docilmente apegados aos seus sentidos, e deste modo, decompostos e isolados uns dos outros, não alcançam uma consciência comum e solidária capaz de compreender que "o embelezamento artificial e a exaltação do individual fazem desaparecer os traços de protesto que estavam traçados na limitação do individual a si próprio em face dos negócios" (ADORNO, 1999, p. 84), pois isto significa a atribuição distorciva de limites econômicos à identidade do indivíduo, condicionando e definindo, por exemplo, a susceptibilidade e o alcance monetário não audível da sua audição, enfim tão manipulada que já perdeu a plasticidade como capacidade de desmentir a estabilidade do existente. Eis o processo de civilização da audição que não pode ouvir o não padronizado, pois este, em sua liberdade exuberante e sedutora, traz em si a autenticidade e a força revolucionária do prazer que conduz a individualidade a uma renovação constante e assim resistente à engrenagem do maquinismo do totalitarismo da cultura de estado oficial. Deste modo traído e iludido, o ouvinte crê ainda desejar o que lhe é oferecido no espaço e no tempo civilizados.

A oficialização cultural cristaliza um pathos de distância presente também no ideal oficial da interpretação que se pode chamar de "barbárie da perfeição". Ou seja, até mesmo na execução extremamente técnica das obras musicais não há espaço e tempo para a individualidade. Aqui, de modo inquestionável, o fetiche é pelo perfeccionismo da execução mais técnica, que se sobrepõe até mesmo aos nomes das obras famosas. "Reina aqui uma disciplina férrea. Precisamente férrea". Ante esse culto quase mítico 
da disciplina, "o novo fetiche, neste caso, é o aparato como tal, imponente e brilhante, que funciona sem falhas e sem lacunas" (ADORNO, 1999, p. 86) para que a interpretação perfeita conserve a obra apresentando-a, no entanto, "como algo já pronto e acabado desde as primeiras notas", isto é, como um produto pré-fabricado sem tensões dialéticas intrínsecas que denunciem as contradições da realidade social. Dentro desse barbarismo da perfeição que constitui uma codificação estereotipada,

As resistências do material sonoro são eliminadas tão impiedosamente no ato da produção do som, que já não há possibilidade de atingir a síntese, a auto-produção da obra, que constitui o significado e a característica de cada uma das sinfonias de Beethoven (...). A fixação conservadora da obra leva à sua destruição, visto que a sua unidade se realiza apenas, precisamente, na espontaneidade, que é sacrificada pela fixação (ADORNO, 1999, p. 86-87).

Eis o fetiche da dominação unilateral do material sonoro sem resistência ante o totalitarismo da fixidez que rejeita e reprime qualquer autoprodução espontânea. A admissão da resistência assistemática enquanto capacidade intrínseca e autônoma do material se oferecer negando a sua completa familiaridade - significaria a concessão de um incômodo espaço para a manifestação da não identidade interior à identidade já há muito estereotipada segundo um código simbólico que exclui a espontaneidade da síntese pela desagregação enquanto promessa de uma reconciliação entre o particular e o universal. Reconciliação que iria contra a civilização como história da desvinculação entre a imagem e a natureza, entre a aparência e a morte, entre o belo e o horrível, enfim, como sobrelevação do visível e recalcamento do audível, que se traduz no recalcamento do feio, do cruel, da tragicidade da beleza, do abandono ao princípio de morte da obra de arte autêntica cuja verdade está no seu impulso mimético de perpetuação do efêmero, isto é, em sua cumplicidade com a morte e em seu acolhimento do não-idêntico ou do não-eu particular. Calando em si o grito de protesto dessa dialética entre o universal e o particular - o grito do material que, ininterrupto, se oferece estranho e que assim atrai um reinvestimento libidinal -, a música de massa ou ligeira 
sequer chega a constituir-se como obra, visto que ela é movida apenas por um instinto de sobrevivência e de conservação da sua identidade fixa que engana o desaparecimento através da repetição da sua imagem inalterada. O totalitarismo se fortalece sobre essa propositada ausência de obras, sem as quais é impotente "o protesto da arte contra a opressão da civilização" (CHIARELLO, 2006, p. 162) que, através da indústria cultural, nega as obras retirando-lhes a intimidade entre o brilho do belo e as cinzas da morte, levando ao culto da beleza visível por parte de "uma cultura calcada no escamotear do sofrimento e do horrível" (CHIARELLO, 2006, p. 165), e que assim cultua uma arte degradada em mercadoria, fruto do "impulso mimético nascido da revolta contra a morte" que caracteriza o processo civilizatório como uma tendência apolínea de eternização através das imagens que se querem responsáveis pela estabilidade.

Embora não seja obra, a música ligeira se dissimula muito bem, elaborando-se de tal modo que ela leva o ouvinte a acreditar e a aceitar sua onipresença, então cultuada como uma coisa que é apenas o seu aparecer presente sem passado e sem futuro, e que sendo assim configurada, mantém a dependência do ouvinte conformado, porque esmagado pelo espaço sociocultural homogêneo e por essa ausência de tempo, que lhe retiram tudo, e deste modo tão pobre, o indivíduo não pode ter sequer recordações e esperanças que o protejam da desintegração renovada sem qualquer novidade. Diante disto, a audição não é uma resposta elaborada a uma questão que lhe foi dirigida, mas, sem exigir-lhe nenhum esforço reflexivo ou de consciência, a audição inerte apenas re-age automaticamente aos estímulos mecânicos da relação coisificada entre a produção e o consumo que rege a música-produto, que manipula a consciência da grande massa dos ouvintes que sacrificam suas individualidades em prol de uma sintonia coletiva com a música fetichizada. Esse é um falso sacrifício daqueles que, contrariamente a Penteu que fez da profecia o seu destino, se recusaram a ser flagrados e destroçados pelas Mênades, que se encontrando no Tonuntergrund intimamente excitadas pela própria origem supra-individual e lírica da música, não reconheciam nenhum ouvinte, apresentandose apenas como a sonoridade a-simbólica pela qual aflora o subsolo originariamente lírico, em seu jogo-criança inocente, e assim trágico. 
Colocarmo-nos na condição verdadeira de autênticos ouvintes sem cera industrial nos ouvidos, resistirmos à mortificação civilizatória da audição como manutenção e controle de uma identidade repetível, significa ouvir o próprio destino como melodia originária da linguagem do prazer e desprazer, significa sermos Penteu e de modo escondido nos tornarmos ouvintes de uma música menádica que irá nos destroçar.

\section{Referências}

ADORNO, T. W. O fetichismo na música e a regressão da audição. In: . Textos escolhidos. São Paulo: Nova Cultural, 1999. . Filosofia da nova música. São Paulo: Perspectiva, 1989.

BARBOSA, R. Música, racionalidade e linguagem. In: . DUARTE, R.; SAFATLE, V. (Org.). Ensaios sobre música e filosofia. São Paulo: Humanitas, 2007.

BARRETO, M. H. Subjetividade e o novo na arte: reflexões a partir de Adorno. Kriterion, Belo Horizonte, v. 33, n. 85, p. 49-58, jan./jul. 1992.

CHIARELLO, M. Natureza-morta: finitude e negatividade em T. W. Adorno. São Paulo: Edusp, 2006.

DAHLHAUS, C.; EGGEBRECHT, H. Que é a música? Lisboa: Texto \& Grafia, 2009.

DUARTE, R. Adornos: nove ensaios sobre o filósofo frankfurtiano. Belo Horizonte: Editora da UFMG, 1997.

MACHADO, Roberto. Zaratustra, tragédia nietzschiana. Rio de Janeiro: Jorge Zahar, 2001.

MENEZES, F. Apoteose de Schoenberg. São Paulo: Ateliê Editorial, 2002.

NIETZSCHE, F. Música e palavra. Discurso: música e filosofia. São Paulo, n. 37, p. 167-181, 2007.

. O nascimento da tragédia ou helenismo e pessimismo. São Paulo:

Companhia da Letras, 1992. . Assim falava Zaratustra. São Paulo: Logos, 1959. 
SAFATLE, V. Fetichismo e mimesis na filosofia da música adorniana. Discurso: música e filosofia. São Paulo, n. 37, p. 365-406, 2007. TOMÁS, L. Música e filosofia: estética musical. São Paulo: Irmãos Vitale, 2005.

WAIZBORT, L. Estilo musical da liberdade. Kriterion, Belo Horizonte, v. 33, n. 85, p. 31-48, jan./jul., 1992.

Data de registro:06/08/2012

Data de aceite: $28 / 09 / 2012$ 